\title{
Development potential of native fish in Batang Toru Watershed, North Sumatra, Indonesia: discussion on the impact of dam development and aquaculture efforts
}

\author{
Dadang Shafrudin ${ }^{1}$, Sulistiono ${ }^{2, *}$, Charles P. H. Simanjuntak ${ }^{2}$, M. Fadjar Rahardjo ${ }^{2}$, Dudi \\ M. Wildan ${ }^{2}$, Totok Hestiranoto ${ }^{3}$, Thomas Nugroho ${ }^{4}$, and Agus Joko Ismanto ${ }^{5}$ \\ ${ }^{1}$ Department of Aquaculture, Faculty of Fisheries and Marine Sciences, IPB University, Bogor. \\ 16680, Indonesia \\ ${ }^{2}$ Department of Aquatic Resources Management, Faculty of Fisheries and Marine Sciences, IPB \\ University, Bogor. 16680, Indonesia \\ ${ }^{3}$ Department of Marine Sciences and Technology, Faculty of Fisheries and Marine Sciences, IPB \\ University, Bogor. 16680, Indonesia \\ ${ }^{4}$ Department of Fisheries Resources Utilization, Faculty of Fisheries and Marine Sciences, IPB \\ University, Bogor. 16680, Indonesia \\ ${ }^{5}$ Department of Environment, PT North Sumatera Hydro Energy, Jl. Darmawangsa VII No. 2, \\ Jakarta, 12160, Indonesia
}

\begin{abstract}
As one of the sizable rivers in the Sumatra region, the Batang Toru River is a habitat for various fish species, some of which are potential to be developed as cultured fish. This study was carried out in April, July, and October 2019 in the Batang Toru River watershed of South Tapanuli Regency, North Sumatra, to evaluate a potential development of the riverine fish for aquaculture development. The methods used were fisheries surveys and discussions with various communities and related agencies in the South Tapanuli Regency. The data obtained were presented descriptively. Based on the result of data analysis collected in the field, there were several potential fish species to be cultured in this study, including mahseer (Tor tambroides, T. tambra, Neolissochilus soro), catfish (Hemibagrus spp.), and eel (Anguilla bicolor). Some people in the area have also developed the culture of several fish species, such as mahseer and catfish. However, there has been no eel rearing until now, although some locations around the Batang Toru River are suitable for freshwater fish aquaculture activities.
\end{abstract}

\section{Introduction}

Sumatra Island has several rivers that mostly flow to the east (Malacca Strait), with only a few flowing to the west (Indonesian Ocean). Some rivers flowing westward include the Batang Toru River, Alas River, and Tripa River. The Batang Toru River, as one of the

\footnotetext{
* Corresponding author: onosulistiono@gmail.com
} 
largest rivers in North Sumatra, could potentially be used as a source of electricity, agricultural needs, plantations, fisheries, tourism, and the livelihood needs of the surrounding community. The development of potential freshwater fisheries (including river fish) is also quite promising. However, with the increasing varieties of interests, including industries, agriculture, fisheries, and settlements, the possibility of contamination (the entry of waste into rivers) will also increase. One effort that can be carried out to increase fisheries production is through aquaculture activities.

Batang Toru River, with a length of about $69.32 \mathrm{~km}$, is administratively in South Tapanuli and North Tapanuli Regencies. The river possesses potential fishery resources that become an essential aspect of the river ecosystem. It is also a river targeted for dam construction for electricity resources in the North Sumatra region and its surroundings. In connection with the dam construction activities that will be carried out in this river, it is estimated that there will be an impact on the fish inhabiting the area, especially on migratory fish species. Therefore, it is essential to get a picture of the aquaculture development of such fish species.

Several studies on fish and fisheries in the river of Sumatra Island were carried out, including in the Lakitan River (Musi Rawas) [1], Kelingi River (Lubuk Linggau) [2], Batang Toru River (South Tapanuli) [3], Asahan River (Tapanuli) [4], Sopokomil River (Dairi) [5], and Enim River (Muara Enim) [6]. Several studies related to the ecology and biology of organisms in this river were carried out by several researchers, i.e., phytoplankton [7], zooplankton [8], macrozoobenthos [9], and mahseer movement [10]. However, there has been no information on the potential aquaculture development of Batang Toru River fish. Therefore, it is essential to conduct this study in these areas. This study aims to analyze the potential of river fish culture in the Batang Toru watershed. The information obtained is needed in the context of developing river fisheries.

\section{Methods}

\subsection{Time and location}

The study on the development potential of native species in the Batang Toru watershed was conducted three times (April, July, and October 2019). The observation lasted 4-5 days for each session at the watershed. The study also included the river area (as fish habitat) and fish farming on fish ponds around the river. The study sites were located in several villages around Batang Toru Watershed (Figure 1), of South Tapanuli Regency, i.e., Marancar, Simaninggir, Huraba, Sipenggeng, Hapesong Baru, Sianggunan, Aek Pining, Bandar Tarutung, Wik 1, Mabang Pasir, Batu Mundom, Huruaya, Simanggiri, Aek Parsaliran, Ishoma (Padang Lancat), and Bandar Hapinis, 


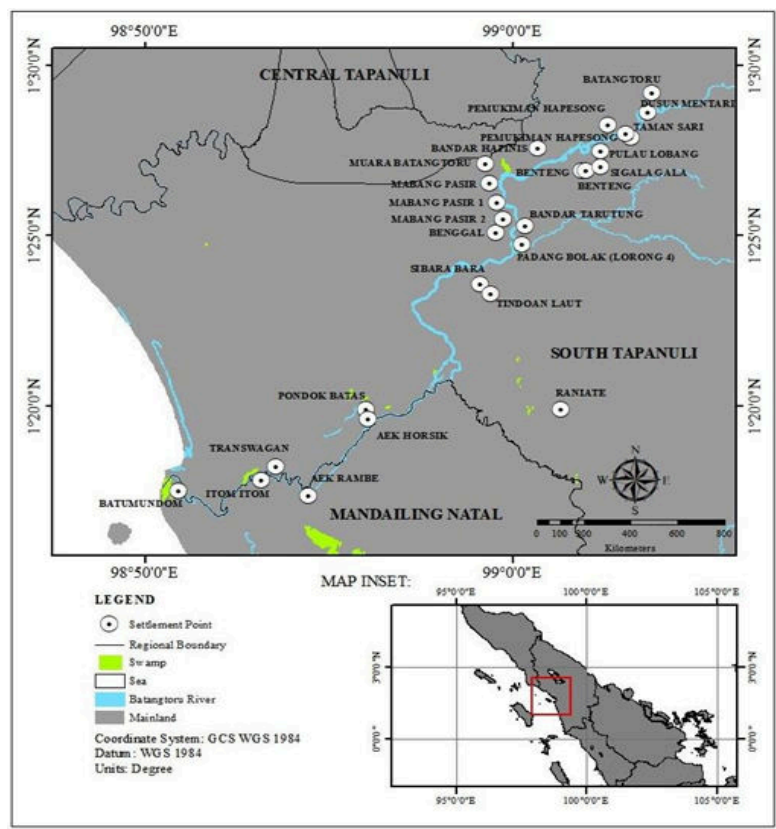

Fig. 1. Study area on the habitat conditions and fish farming development in Batang Toru River.

\subsection{Data collection}

The data collection method was carried out through stratified random sampling by selecting several people (respondents) who generally have fishing activity and culture fish. Data on habitat conditions, river fishery activities, and pond conditions in aquaculture development were obtained through direct observations in the field and interviews with the community. The respondents were determined through purposive sampling $(\mathrm{n}=30$ people). In collecting data through interviews using a questionnaire, several questions were asked and discussed to the respondents, i.e., fishing activities in the river, fishing gears used in the fishing activity (hand line, gill net, cast-net, bamboo traps), species of fish commonly caught, marketing of fish caught, wishes for aquaculture, and species of fish commonly cultured. The data obtained were analyzed descriptively.

\section{Results}

\subsection{Data collection of riverine habitats and fish potential for aquaculture development}

The study on river fish habitat and potential fish species was carried out by tracing some fish habitat areas and aquaculture sites in the Batang Toru Watershed. In the study, highvalue fish species such as mahseer (Tor tambroides and Neolissochilus soro), eel (Anguilla bicolor), and catfish (Hemibagrus spp.) were observed in Batang Toru River and its tributaries.

Adult mahseer fish measuring 366 grams and 1236 grams body weight was found in the Batang Toru River upstream. In downstream, part of the main-sized fish was in the river, emptying into Lake Siais (Raneate Region). The community called "prohibited water" (daerah larangan-in Indonesian) in this part of the river. Prohibited water is a segment of 
the river where the public is prohibited from catching fish within an agreed timeframe [3]. On some occasions, especially in the dry season, the water discharge was reduced to decrease the water level, resulting in the death of the fish in the protected area.

The fish in the Batang Toru River, especially during the dry season, are commonly found in the relatively deep-water areas called deeper parts of the river (lubuk-Indonesian). Some tributaries of the Batang Toru River are expected to be areas of spawning and growth, such as Malakut and Marancar Rivers (Figure 2).

Almost all life cycles of fish found in the Batang Toru River occur in the river and its tributaries, except for fish that carry out anadromous migration, i.e., eel. This fish, during a spawning season, migrates to the ocean for spawning purposes. The fish in the leptocephalus stage returns to the river mouth to live and grow along the river until it becomes adult (broodstock). Adult eels in this study were found both downstream (Anguilla bicolor) and upstream (Anguilla marmorata, in Sipirok and Marancar).

In the Batang Toru River section of the Marancar area, mahseers were often caught with more than $1 \mathrm{~kg}$ in body weight. Mahseer juveniles were commonly found in the tributaries whose waters are shallow in the Marancar region. Infield observations, a search was done at places where according to the fishers, were deeper parts of the river with lots of fish and were thought to be the spawning grounds for the mahseers. Based on the study conducted by tracing of areas (Bandar Batu to Aek Batang Guarna), there were nine deeper parts in the river (lubuk-Indonesian). The fishers named them Lubuk Bandar Batu and Lubuk Jebua (around mouth of Aek Batang Guarna) (Figure 2). Other deeper parts known to the public throughout Marancar-Sipirok included Langean, Sigura-Gura, Tondola, Dakkapote, and Haruaya.
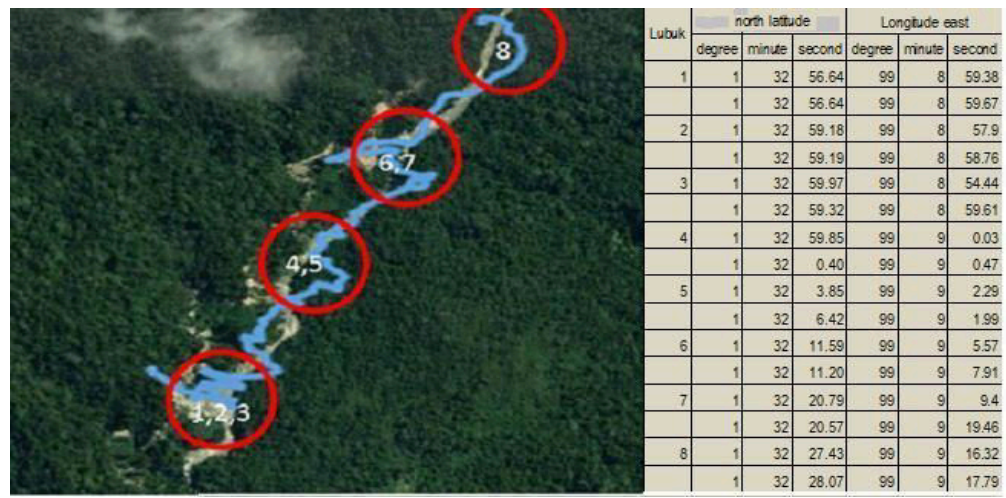

Fig. 2. The position of the deeper parts of the river (lubuk-Indonesian) along Bandar Batu and Aek Batang Guarna areas.

\subsection{Integration of aquaculture and catch fisheries}

Based on fish species found, especially fish that were expected to be migratory species, the Tor spp. Figure 3 is one fish species that can be cultured and farmed. Some Research Centers and communities can breed Tor spp. in Indonesia, such as West Java, Jambi, and North Sumatra Provinces. In Jambi, the Neolossochilus soro species can be bred for several years and kept in ponds [11]. While T. tambra and N. soro can be bred in Bogor. Another fish species that also has the prospect of being bred is N. sumatranus, a group of Cyprinid fish that is quite popular among local people. 


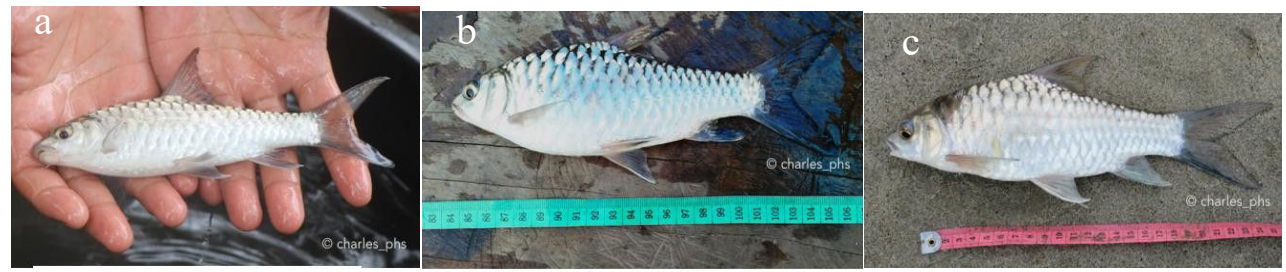

Fig. 3. Types of mahseers: Neolissochilus soro (a), Tor tambra (b) and T. tambroides (c).

In general, the decline in fish productivity in inland waters is due to an increase in fishing intensity and habitat damages caused by human activities. Fish culture activities (growing and breeding fish in a controlled manner) can solve the problem in the affected location through several methods (discussed with types of issues to be expected). Based on the development of mahseer farming, it is necessary to mention the existence of aquaculture efforts in the running water, which are divided into four methods, as follows:

Method 1: Mahseer requires a specific place to spawn, i.e., a rocky, sandy area with a water flow to stimulate the fish to spawn naturally. In this case, such a place was conserved.

Method 2: The absence of suitable places for spawning because of the water flow problem can be overcome through artificial spawning in aquaculture activities. In this method, holding and spawning ponds are built near the place where adult fish can grow until they reach a mature gonad stage but cannot spawn because of the water problem. In the breeding season, the brood fish are caught and selected to determine the gonad maturity stages. After the adaptation period in the holding pond of 1-2 days, the fish are naturally spawned in the spawning pond through hormonal injections. The egg or larva is then transferred and stocked in the nursing area in the Batang Toru River. This method is the simplest method of fish restocking. Fish pond models or designs are presented in Figure 4.

Method 3: Habitat destruction due to the dam's construction causes adult fish to move to other places. In such conditions, the hatchery activity begins with providing and maintaining farmed adult fish until their gonads are mature. Hatchery facilities are needed to spawn the broodfish, incubate eggs, and rear larvae. After the fish reach fingerling size, they are stocked in the Batang Toru River. This method of seed production is suitable for government-owned hatcheries, i.e., Sibulele Fish Hatchery in Batang Angkola and NSHE (North Sumatra Hydro Energy) fostered fish hatchery in Padang Lancat.

Method 4: The electricity company (NSHE) facilitates the supply of mature gonad brood. Those broodfish are used in the hatchery business by fish farmers. Seed yields are partly sold by farmers, while the rest are stocked into public waters.

The success of this method can be pursued by applying it to reserve river area (prohibited area) as a place of stocking (restocking) whose management involves institutions capable of managing businesses.

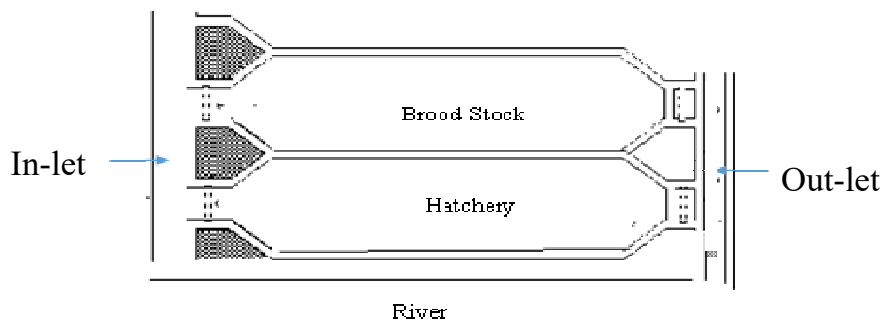

Fig. 4. Fish culture design in the Batang Toru area. 


\section{Discussion}

The potential of aquaculture resources in Indonesia is quite significant with the diverse species that are economically valuable for farming. However, the utilization has not been maximized, so that the fisheries sector's contribution to development and economy in general (and an increase in the standard of living of the community of fish farmers) are not optimal [12]. So far, the aquaculture sector has promised a future for the Indonesians, not only because of abundant natural resources but also due to the management system that continues to improve [13]. It is not exaggerated to say that with such diverse and abundant aquatic resources, aquaculture will later dominate non-oil and gas exports and be a guarantee for the future of all Indonesians in overcoming the food crisis, especially with the increasing demand for high protein foods and high export demand from developed countries [14].

Batang Toru River is where the dam will be built as a source of electricity in North Sumatra. Based on the study of water quality and aquatic biota conducted, the river is still classified as good (natural). Water conditions in some areas are bright and quite turbid. Furthermore, to date, there have been no pollutions in this river [11]. Like a river which becomes a habitat for several fish species, the planned construction of the dam will affect the life cycle of the fish inhabiting it, especially the migratory fish species, i.e., potamodromous (mahseer, Tor spp.) and anadromous (eel, Anguilla spp.) [15]. Also, the dam's existence will affect people who depend on the river (as one of their livelihoods), especially for fishing activities [16]. It will also have an impact on the income of the local community.

Dam construction has an impact on reducing the flow speed and depth of water in the river basins between the dam and the end of the tunnel. This condition has the potential to disturb the mahseer broodstock life cycle, breeding, and feeding habits. Thus, fish will find other places to spawn.

Changes in habitat can disrupt water flow (discharge and speed) in the form of a. Reduction in the area where the fish grow and reach gonadal maturation, b. Reduction in habitat for reproduction (spawning ground), and c. Changes in areas suitable for growing out of fish shrink into expanding nurseries

A dam blocks feed supply through water flow from the upper reaches of the Batang Toru River. At the same time, the fruits are not immediately available in the stream because they fall on the edge of the drying river and will enter the stream when the river water rises or drift along with the rainwater flow. To maintain and increase fish productivity, some efforts can be made:

a. Protecting the remaining natural or artificial protected parts of the river (lubukIndonesian) by making them protected pits by the local customary rules or the government from the exploitation of fish that endangers their preservation. Through that, they can live there, grow, and breed. The downstream of the river is affected based on the calculation of water discharge from both the spillway dam and the tributary that empties into Batang Toru River (which still has potential as a place for fish growth, spawning, and distribution, including the area around the mouth of the river of the Malakut River).

b. Arranging the allotment of affected areas by making fish habitats suitable for certain stages to live and grow well.

c. Conserving the existence or planting, which are natural food sources of fish in areas that still receive the flow up to the edge of the river.

d. Restocking fish in affected rivers as a part of an integrated effort to fishery and aquaculture. 
Eel rearing needs further study to see whether the existence of eel in the location of the area around the dam is quite significant both in the current economic role and ecological role as a source of broodstock.

Mahseer requires a reasonably large water flow. They live in the deeper area and its surrounding. Water flow, current direction, type of sediment, and depth of the waters in the subsoil have the same phenomenon, i.e., gravity. Therefore, Sabar and Rahmatika [17] distinguished fish habitat types based on the current velocity and variety of water beds (Fig. 5).

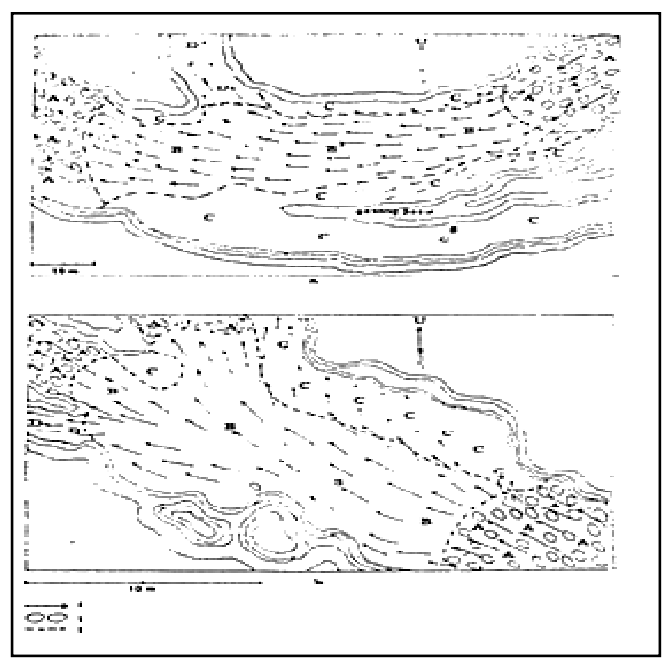

Fig. 5. Water flow and current direction in the river [13].

The first habitat type, or habitat type A, is where the water comes out and goes into a hefty current with an average speed of $2.5 \mathrm{~m} / \mathrm{second}$ (range $2-3 \mathrm{~m} / \mathrm{seconds}$ ). Large rocks dominate the bottom of the water with a diameter of more than one meter. The habitat type $\mathrm{B}$ covers an area of a mid-deeper part of the river (lubuk-Indonesian) with an average depth of $1.25 \mathrm{~m}$ (range $0.75-1.50 \mathrm{~m}$ ), an average current speed of $1.6 \mathrm{~m} / \mathrm{seconds}$ (range $1.2-1.8$ $\mathrm{m} /$ seconds), and bottom waters ranging from gravel to medium size rocks with a diameter of $0.75 \mathrm{~m}$. Habitat type $\mathrm{C}$ is a suburb of the pit with a depth of less than $0.5 \mathrm{~m}$. It has a slow current or less than $0.8 \mathrm{~m} / \mathrm{second}$ - and consists of sand, gravel, to rocks with a diameter of $0.5 \mathrm{~m}$. Inundated areas are only flooded with water in the bottom of the sand. Small stones are also included in habitat type C. Habitat type D is between type B and type C, where the water current is moderate or an average of $1.6 \mathrm{~m} / \mathrm{second}$. It consists of sand and gravel, which are relatively uniform. This place is a branch of water coming out from the bottom that does not follow the mainstream.

Spawning ground for mahseer, assumed to be the same as for T. tambra and other fish species, is similar to habitat $\mathrm{C}$ but requires other aspects in the form of sediment conditions and water quality associated with flooding. Thus, the nesting site is the fragmentation of habitat type C. Eggs are placed in habitat type $C$ that borders habitat type A, a bend in the water that causes currents to move to the edge. The bottom waters consist of $2 \mathrm{~mm}$ diameter coarse sand clean from dirt and mildew with clear water.

Aquaculture development for mahseer and fish hatchery activities is a challenge for the community and related agencies (Office of Fisheries and Marine Affairs-OFMA of South Tapanuli Regency). The existence of an incubator is felt to be very important, especially in preserving the fish so that it does not become extinct in the region. In planning the dam's construction in the Batang Toru River, the community involvement in fisheries management is essential, through guidance in conducting the mahseer spawning activities. 
These efforts have been quite successful with the number of seeds that can be spread on several inland waters to restock these fish in nature.

The challenge faced in the mahseer farming business is the lack of community interest in aquaculture because it seems that the rearing period is very long. Growing the fish to the size of consumption may take more than one year. Therefore, in the subsequent business development, it is necessary to create business segments that allow fish farmers to conduct aquaculture activities in each of their parts quickly (3 months) and obtain good yielding. The portions are hatchery, larvae rearing, and enlargement (grow out rearing) business delivered in the program roadmap (Figure 9). Efforts to develop freshwater fish have been carried out by several researchers [18-20]. The hatchery business was initiated by one of the residents in the South Tapanuli Regency, who produced $2 \mathrm{~cm}$ total body length seeds. Local people can raise these fish seeds for three months until they reach $5 \mathrm{~cm}$ in total body length. Next, the larvae rearing farmers can keep the fish up to $8 \mathrm{~cm}$ in size for three months and sell them back to the next further rearing farmer, and so on until finally, the grow-out fish farmer produces consumption size fish by rearing the $12 \mathrm{~cm}$ size seeds for three months.

The rearing and grow-out farmers can also obtain seeds of 5 to $12 \mathrm{~cm}$ total body length from the capture of natural seeds from the Batang Toru River. To run this business model, a kind of pilot project, which has the support of various institutions, such as cooperation between structural agencies, companies, and universities, is required by synergizing their respective roles. From this activity, mahseers are expelled even though there is a reduction in habitat (river) due to a dam, but the production can be increased through breeding and rearing activities. These fish can also be the target of restocking activities in nature to preserve local (native) fish resources.

In handling eel, it is also essential to take care of the size of the fish seedlings in which an individual weighs $0.5-1 \mathrm{~kg}$. The fish can be farmed, and then it can be sent to Java to be further maintained or can be directly exported to Japan. Similar conditions are also carried out in the Pelabuhan Ratu area of West Java Province. There are several eel farmers in this area, both by the community and the companies (Indonesian and foreign companies). After being reared, these fish can be sent to Jakarta or abroad for export. Aquaculture activities with the integration between capture and aquaculture are shown in Fig. 6.

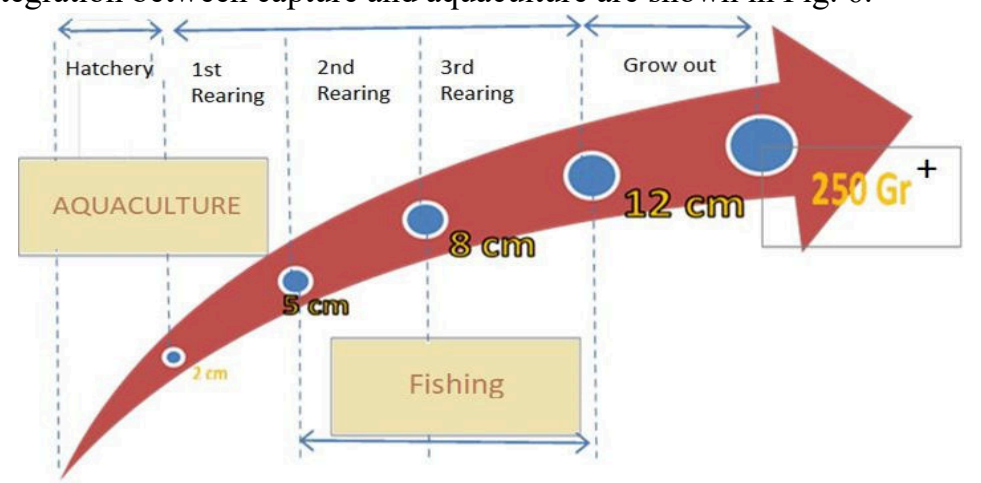

Fig. 6. Linkages between fishing activities and aquaculture segments reaching the final size of fish consumption.

When the broodstocks from the affected area move to other places, followed by their successful breeding in the Batang Toru River area at the top of the water tunnel outlet, which is affected by the reduction in water discharge, that place can be turned into a fish seed habitat. The exploitation of young fish carried out by fishers will reduce their income if used as consumption fish carried out by the people catching fish around Aek Parsarian Area. Even though there is much young fish, the biomass of the catch is lower than that of the smaller size adult fish. The price of adult fish is also high (Rp80.000 per kg). Efforts to 
make a "lubuk" (more profound part of the river) for fish growth to reach adulthood will be influenced by the limitations of natural foods (which rely on tributaries) because, in Batang Toru River, the food supply is cut off.

Aquaculture development will be able to overcome the above problems. The use of young fish as seeds for aquaculture business can increase the price of young fish. Based on interviews and visits to the aquaculture sites, the potential of community resources was determined. Fish Hatchery Center (FHC) of Butana Dua has some ponds which are currently used to produce carp, tilapia, and catfish. Shortly, FHC is expected to play a role in developing mahseer culture, such as breeding fish seeds that can already be produced by the community, producing cultivation technology, and providing seeds for further nursery and rearing activities in the community. The settlements and community activities of FHC have negatively affected water quality, making it impossible for mahseer culture. Information from the Head of FHC of Batuna Dua and staff also suggested that the development of mahseer can be conducted at other FHC, namely, Sibulele FHC in the Batang Angkola area.

The local people farmed fish in ponds in some areas along the Batang Toru River, such as Sianggunan, Hapesong Baru, Aek Pining, WIK 1, Ishoma (Padang Lancat) and Sisipa. During the field observation in Sianggunan, the irrigation was proper, and the rehabilitation of the ponds was required so that they could be used for mashser farming. Likewise, on the visit to Huraba and Sipenggeng areas, it was found that there were ponds with limited irrigations (according to the community members, the discharge could still be increased) that could be used for mahseer culture.

Technology that has been adaptive to Sipirok and Marancar, for the initial stage, can imitate the cultivation conducted by farmers in Padang Lancat. The perspective of mahseer fish farming ranges from breeding to growing out. However, the technology still needs to be modified/developed. In Sipenggeng and Huraba, the ponds have been used for rearing carp and tilapia. Two mahseers were also found in the stagnant water pond, each weighing up to more than $1 \mathrm{~kg}$.

Mahseer (Tor douronensis) is one of the 4 species of mahseers found in Indonesia. Other species are T. tambra, T tambroides, and $N$. soro. Fish species similar to mahseer are also found in other regions, i.e., in Java and Kalimantan. This fish species in the Kuningan region (West Java) include fish that have been reared by the local community [21]. However, in the other areas, these fish are also developed and consumed by the local community. In the Garut area (West Java), T. soro fish are costly and become a target fish to be developed. In the area of Central Java, people call mahseer "Tambra" fish ( $T$. tambroides). "Tambra" is a consumption fish whose meat is thick, sweet, and rich in fish oil with good tastes and high prices [22]. Tambra fish's body size is very exotic because it can reach above $30 \mathrm{~kg}$ body weight with a body length of more than $1 \mathrm{~m}$ [23]. Haryono [24] managed to catch a tambra fish weighing $20 \mathrm{~kg}$ in the upper reaches of the Barito River in Central Kalimantan, and even the residents informed that in the 1990s, that type of fish weighed $50 \mathrm{~kg}$. Tambra fish meat is very popular with local and overseas communities with high prices.

In the development of riverine fish culture, especially mahseer, it is vital to have community involvement, particularly in the supply of seeds (Sudarmaji, [25]; Subagja \& Juli, [26]), nursery and rearing activities. If the community can master the technology of these activities, it is also vital to develop processing and marketing activities. It is also essential to hold partnership programs with various private and government institutions in fish development activities. Mahseer can be processed with a variety of preparations, sold as raw fish, and processed into a range of processed products such as curry, meatballs, nuggets, etc. Thus, many people can enjoy these products with a broader market, for instance, Jakarta, Kuala Lumpur, etc. 


\section{Conclusion}

Batang Toru River is a habitat for several migratory fish with enormous potential to be cultured such as mahseer and eel. Based on the survey results, a reduction of water discharge in the Batang Toru River will impact and disturb the mahseer fish population, decreasing spawning habitat and nursery ground for young fish. Technically, the reduction of young fish populations in the affected areas can be overcome by restocking that involves aquaculture activities. The development of aquaculture activities, especially mahseers in the Batang Toru watershed and surrounding areas, is significant to be implemented. These conditions not only lead to new businesses that have high economic prospects but also to the context of preserving local fish resources.

The authors would like to thank PT. North Sumatera Hydro Energy supported and funded this study. Thanks are due to some field assistants, particularly Mr. Saleh Ritonga, Mr. M. Faizal Muhjafar Sulistiono, Mr. Arief Irfan Prasetyo, Mr. Pasca Rianto, and Mr. M. Zainuri, for their dedicated fieldwork during the study.

\section{References}

1. D. Samitra, Z.F. Rozi, J. Biodjati 4, 11 (2019)

2. D. Samitra, Z.F. Rozi, J. Biota 4, 1 (2018)

3. D.I. Roesma, A. Chornelia, A. Mursyd, M. Kamsi, Biodiversitas 17, 628 (2016)

4. C.P.H. Simanjuntak, Proc. Natl. Fish Semin. VII, 43-60 (2012)

5. C.P.H. Simanjuntak, J. Iktiologi Indones. 12, 155 (2017)

6. A. Hamidah, J. Iktiologi Indones. 4, 51 (2004)

7. A. Asriansyah, D.M. Wildan, N.T.M. Pratiwi, C.P.H. Simanjuntak, Sulistiono, T. Hestirianoto, D. Shafrudin, T. Nugroho, IOP Conf. Ser.: Earth and Environ. Sci. 800 (2021)

8. A. Asriansyah, D.M. Wildan, N.T.M. Pratiwi, C.P.H. Simanjuntak, T. Hestirianoto, D. Shafrudin, T. Nugroho, Sulistiono, IOP Conf. Ser.: Earth and Environ. Sci. 800 (2021)

9. D.M. Wildan, Sulistiono, C.P.H. Simanjuntak, M.F. Rahardjo, T. Hestiranoto, D. Shafrudin, T. Nugroho, A.J. Ismanto, IOP Conf. Ser.: Earth and Environ. Sci. 744 (2021)

10. T. Hestirianoto, Sulistiono, D.M. Wildan, C.P.H. Simanjuntak, M.F. Rahardjo, D. Syafruddin, T. Nugroho, A.J. Ismanto, IOP Conf. Ser.: Earth and Environ. Sci. 744 (2021)

11. Sulistiono, M.F. Rahardjo, T. Hestirianoto, C.P.H. Simanjuntak, Nugroho, D.M. Wildan, A.I. Prasetyo, P. Rianto, M. F. M. Sulistiono, M. Zainuri, Study on Migratory Species in Batang Toru River, North Sumatera (in Bahasa Indonesia) (2019)

12. V.A.S Adi, Analysis of aquaculture fisheries (in Bahasa Indonesia) (Marine and Fisheries Extension Center, Jakarta, 2011)

13. P.J.G. Henriksson, L.K. Banks, S.K. Suri, T.Y. Pratiwi, N.A. Fatan, Environ. Res. Lett. 14, 124062 (2019)

14. M.A. Rimmer, K. Sugama, D. Rakhmawati, R. Rofiq, H. Habgood, Rev. Aquac. 5, 255 (2013)

15. C.P.H. Simanjuntak, Sulistiono, M.F. Rahardjo, T. Hestiranoto, D. Syafrudin, T. Nugroho, A.J. Ismanto, Fish fauna of the Batang Toru River, North Sumatra, 
Indonesia (in Bahasa Indonesia) (2020)

16. T. Nugroho, Sulistiono, M.F. Rahardjo, C.P.H. Simanjuntak, T. Hestiranoto, D. Syafrudin, A.J. Ismanto, Utility of Batang Toru River (North Sumatera of Indonesia) for fisheries activity by local community: study on fisheries socio-economic condition (in Bahasa Indonesia), IPB University, 2019

17. F. Sabar, I. Rachmatika, Zoo. Indonesia 2, 1 (1983)

18. Rahmawati, Hartono, Naturalis 1, 129 (2012)

19. B.D. Nugroho, H. Hardjomidjojo, M. Sarma, Manaj. IKM. 12, 127 (2017)

20. B.C.G.S. Worang, H.J. Sinjal, R.D. Monijung, J. Budid. Perair. 6, 68 (2018)

21. Ratnawati, Ayo Bandung.com. (2019)

22. Anonymous, Sarawak Timber Association Review 120, 4-6 (2003)

23. Haryono, Biodiversitas 7, 195 (2006)

24. Haryono, J. Iktiologi Indones. 4, 2 (2004)

25. Sudarmaji, Bul. Tek. Litkayasa Akuak. 13, 83 (2015)

26. J. Subagja, M. Juli, FITA, 875-883 (2014) 